\title{
Penerapan Algoritma Apriori Terhadap Data Penjualan Di Swalayan Koperasi Bappenas Jakarta Pusat
}

\author{
Siti Aisyah $^{1}$, Normah ${ }^{2}$ \\ ${ }^{1}$ STMIK Nusa Mandiri \\ e-mail: sitiaisy0705@nusamandiri.ac.id \\ ${ }^{2}$ STMIK Nusa Mandiri \\ e-mail: normah.nor@nusamandiri.ac.id
}

Cara Sitasi: Aisyah, S., \& Normah, N. (2019). Penerapan Algoritma Apriori Terhadap Data Penjualan Di Swalayan Koperasi Bappenas Jakara Pusat. Paradigma - Jurnal Komputer dan Informatika, 21(2), $235-242$. doi:10.31294/p.v21i2.6205

\begin{abstract}
Supermarkets are a place to supply daily necessities ranging from nine basic commodities to household needs. Every day there are several sales transactions, which that data will increase continue. Usually these sales data are only used as store archives, actually in sales data there are information that can be used to find out the most sales simultaneously so that a method is needed to find out which products has selling well using apriori algorithm and tools rapid miner help. From the results of analyzing the sales data, consumers who conduct basic needs product transactions obtained from the purchase of dominating item combinations are a combination of Indocafe Jar $200 \mathrm{~g}$ and Kapal Api $165 \mathrm{~g}$ items with the highest support value of 0,213. Then, the buyers of item combination which dominates Max Creamer $450 \mathrm{gr}$ item and Kapal Api $165 \mathrm{gr}$ confidence value are 0,958 and the buyrs combination of Gulaku Kuning and Kapal Api $165 \mathrm{~g}$ support value are 0,259 From these results, concluded every consumer buys Indocafe Jar $200 \mathrm{~g}$ there is an indication that consumers will also buying Api Kapal Api $165 \mathrm{gr}$ as well as Gulaku Kuning with Kapal api $165 \mathrm{~g}$ and Max Creamer 450gr and Kapal Api $165 \mathrm{gr}$.
\end{abstract}

Keywords: A Priori Algorithm, Basic Needs, Transactions

\section{PENDAHULUAN}

Persaingan bisnis dalam perdagangan dunia melalui ekonomi pasar bebas dan kemajuan teknologi informasi menuntut para pengembang untuk menemukan suatu strategi yang diinginkan oleh pelanggan yang pada tingkat persaingannya semakin ketat dan semakin terbuka untuk memenuhi kebutuhan pelanggan juga semakin tinggi. Dalam penjualan barang (produk) perusahaan sering mengalami masalah karena tingkat belanja konsumen yang tidak beraturan. Penentuan tata letak produk makanan dan minuman dilakukan untuk mempermudah konsumen dalam mencari produk makanan dan minuman sehingga tidak mengecewakan para konsumen dalam mencari letak barang produk mana yang cocok digabungkan dengan produk lain yang sering diminati konsumen sehingga para konsumen bisa menghemat waktu, (Syahdan \& Anita, 2018).

Koperasi Pegawai Bappenas memiliki sebuah toko swalayan yang menyediakan berbagai macam kebutuhan sehari-hari. Produk yang tersedia di koperasi tidak sedikit, lebih dari 1000 jenis produk yang tersedia di koperasi tersebut dengan harga yang bersaing, dan memenuhi hampir semua kebutuhan konsumen sehari-hari. Dalam sehari koperasi dapat melakukan ratusan transaksi yang dimana akan mendapatkan hasil data pembelian dan terus akan bertambah setiap harinya. Berdasarkan permasalahan yang dihadapi perusahaan, maka dibutuhkan alat bantu analisis data mining. Saat ini pemanfaatan data-data yang dimiliki belum maksimal, baru sebatas untuk pembuatan laporan. Data transaski penjualan yang terkumpul dan tersimpan dapat memberikan pengetahuan yang bermanfaat bagi pengambil keputusan dalam melakukan usaha- usaha yang terkait dengan peningkatan penjualan dengan melakukan promosi yang tepat dan mengetahui kebiasaan berbelanja para customer, (Syahdan \& Anita, 2018).

"Data mining sering disebut knowledge discovery in database (KDD), kegiatan yang meliputi pengumpulan, pemakaian data historis untuk 
menemukan keteraturan, pola atau hubungan dalam set data berukuran besar", (Syahdan \& Anita, 2018). "Aturan yang menyatakan asosiasi antara beberapa atribut sering disebut affinity analysis atau market basket analysis", (Siregar, 2014). Di dalam bidang usaha metode association rule mining ini dikenal dengan istilah analisa Keranjang Belanja atau Market basket Analysis. Market basket analysis merupakan sebuah analisis terhadap kebiasaan customer berbelanja untuk menemukan asosiasi dan korelasi di antara berbagai macam items yang akan di beli. Spesifiknya Market basket analysis bertujuan untuk mengetahui items apa saja yang sering dibeli bersamaan, (Wijaya, 2017).

Berdasarkan masalah penelitian ini khususnya dalam menerapkan metode algoritma apriori untuk mengolah data penjualan pada koperasi yaitu, banyaknya transaksi yang terjadi setiap hari membuat data penjualan menjadi menumpuk dan hanya digunakan sebagai arsip dan data penjualan yang tidak digunakan lagi dapat diolah dan dikembangkan untuk mendapatkan strategi pemasaran. Manfaat dan tujuan penelitian ini adalah untuk mengetahui bahwa algoritma apriori dapat membantu mengembangkan strategi pemasaran, mengetahui data produk yang sering dibeli secara bersamaan, untuk membantu petugas koperasi mengatur stok barang dan dapat mengatur tata letak barang dengan meletakan barang yang sering dibeli secara bersamaan.

\section{Data Mining}

Data Mining adalah proses yang menggunakan teknik statistic, matematika, kecerdasan buatan, dan machine learning untuk mengekstraksi dan mengidentifikasi informasi yang bermanfaat dan pengetahuan yang terkait dari berbagai database besar, (Nofriansyah, 2014).

Data mining dibagi beberapa kelompok berdasarkan tugas yang dapat dilakukan, yaitu deskripsi, estimasi, prediksi, klasifikasi, pengklasteran, asosiasi, (Nofriansyah, 2014).

\section{Algoritma apriori}

Association Rule Mining adalah teknik data mining untuk menemukan aturan asosiatif antara suatu kombinasi item. Contoh aturan asosiatif dari analisis pembelian di suaru pasar swalayan adalah dapat diketahuinya berapa besar kemungkinan seorang pelanggan membeli roti bersamaan dengan susu. Penting tidaknya suatu aturan dapat diketahui dengan dua parameter yaitu, support dan confidence, (Nofriansyah, 2014).

\section{METODE PENELITIAN}

Penelitian menggunakan algoritma apriori dengan bantuan software rapid miner untuk menentukan produk kebutuhan pokok yang sering terjual bersamaan pada swalayan koperasi pegawai bappenas. Berikut merupakan langkah-langkah yang digunakan dalam penelitian ini:

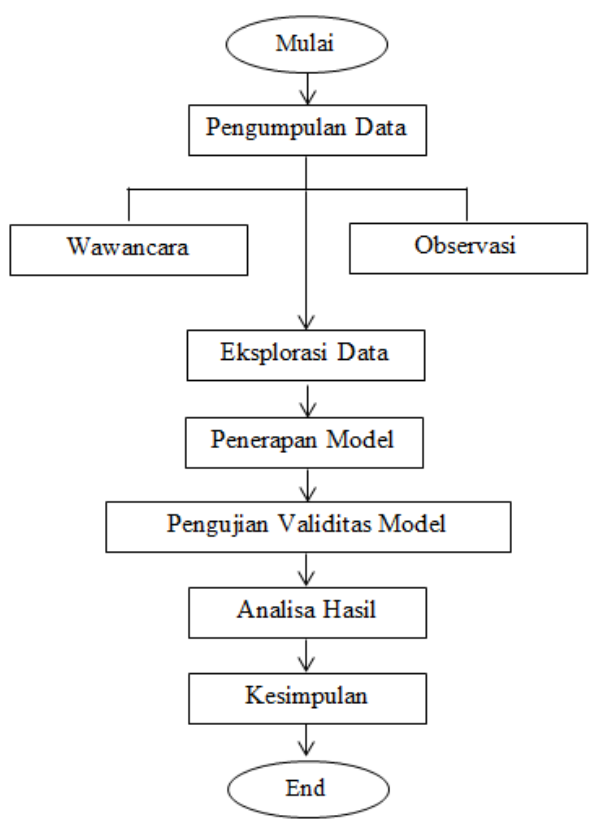

Gambar 1.Langkah - langkah penelitian

1. Pengumpulan Data

Pengumpulan data dilakukan dengan cara melakukan observasi dan wawancara denga petugas koperasi, sehingga peneliti mendapatkan data transaksai penjualan selama 1 bulan. Selama 1 bulan koperasi dapat melakukan transaksi sebanyak 108 pda produk kebutuhan pokok yang terdiri dari beras, minyak, gula, kopi, dan teh.

\section{Pengolahan Data}

Pengolahan data dengan memasukan data penjualan kedalam format tabular.

\section{Metode Yang Digunakan}

Metode yang digunakan pada penelitian ini adalah metode asosiasi data mining menggunakan algoritma apriori. Perhitungan manual menggunakan Excel dan pengujian model dengan bantuan software rapid miner. Dengan tujuan melihat produk apa saja yang laku secara bersamaan pda koperasi. Metode ini memerlukan sebuah parameter untuk menentukan hasil akhir, yaitu

a. Analisis Pola Frekuensi Tinggi, tahap ini mencari kombinasi item yang memenuhi syarat minimum dari nilai support dalam database, yang dapat dirumuskan sebagai berikut:

$$
\text { Support }(A)=\frac{\sum \text { transaksi yang mengandung A }}{\sum \text { transaksi }} \times 100 \%
$$

Sementara nilai support dari kombinasi 2 item set diperoleh dengan menggunakan rumus berikut: 


$$
\begin{aligned}
& \text { Support }(A, B)=P(A \cap B) \\
& \text { Supprot }(A, B) \\
& \text { Support }(A, B)=\frac{\sum \text { Transaksi yang mengandung Adan } B}{\sum \text { Tansaksi }} \times 100 \%
\end{aligned}
$$

b. Pembentukan Aturan Asosiatif, setelah semua pola frekuensi tinggi ditemukan, barulah dicari aturan asosiatif yang memenuhi syarat minimum untuk confidence dengan menghitung confidence aturan asosiatif $\mathrm{A} \rightarrow \mathrm{B}$, (Nofriansyah, 2014).

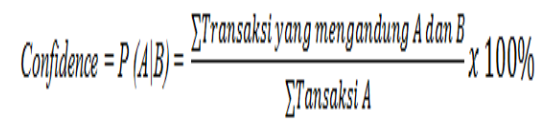

\section{HASIL DAN PEMBAHASAN}

Pada tahap ini di lakukan penghitungan untuk mendapatkan hasil final. Tahapan dalam menganalisa data dengan algoritma apriori pada penjualan produk kebutuhan pokok dimulai dengan menyusun data-data yang ingin di analisis, kemudian disusun semua jenis item produk kebutuhan pokok yang ada didalam transaksi penjualan dan akan dianalisa mengunakan algoritma apriori dengan

\begin{tabular}{|c|c|c|c|}
\hline No & Tgl & No Invoice & $\begin{array}{l}\text { e Nama Barang } \\
\end{array}$ \\
\hline 1 & \multirow[t]{3}{*}{$\begin{array}{c}01- \\
\text { Feb-19 }\end{array}$} & \begin{tabular}{|l|} 
TK- \\
2019II/876 \\
$13 /$ INV
\end{tabular} & $\begin{array}{l}\text { Kapal Api Rasa Mantap, } \\
\text { Kapal Api Spesial Mix, } \\
\text { Kapal Api Susu 32gr }\end{array}$ \\
\hline 2 & & \begin{tabular}{|l|} 
TK- \\
2019II/876 \\
$49 / \mathrm{INV}$
\end{tabular} & $\begin{array}{l}\text { Kapal Api } 165 \text { Gr, Kapal } \\
\text { Api Spesial Mix }\end{array}$ \\
\hline 3 & & \begin{tabular}{|l|} 
TK- \\
2019II/876 \\
$75 / \mathrm{INV}$
\end{tabular} & $\begin{array}{l}\text { Indocafe Coffemix 20gr, Max } \\
\text { Creamer 450gr }\end{array}$ \\
\hline 4 & \multirow{3}{*}{$\begin{array}{c}04- \\
\text { Feb-19 }\end{array}$} & \begin{tabular}{|l|} 
TK- \\
2019II/877 \\
$89 / \mathrm{INV}$
\end{tabular} & $\begin{array}{l}\text { Gulaku Putih, Tongtji Jasmine } \\
\text { Tanpa Amplop }\end{array}$ \\
\hline 5 & & \begin{tabular}{|l|} 
TK- \\
2019II/877 \\
$95 / \mathrm{INV}$ \\
\end{tabular} & $\begin{array}{l}\text { Gulaku Kuning, Teh Celup } \\
\text { Sosro } 30\end{array}$ \\
\hline 6 & & $\begin{array}{l}\text { TK- } \\
2019 \mathrm{II} / 878 \\
85 / \mathrm{INV} \\
\end{array}$ & $\begin{array}{l}\text { Gulaku Kuning, Tongtji } \\
\text { Jasmine, Tongtji Jasmine } \\
\text { Tanpa Amplop }\end{array}$ \\
\hline 7 & \multirow{3}{*}{$\begin{array}{c}06- \\
\text { Feb-19 }\end{array}$} & \begin{tabular}{|l} 
TK- \\
2019II/879 \\
$96 / \mathrm{INV}$ \\
\end{tabular} & Kapal Api 165 Gr, Sariwangi 50 \\
\hline 8 & & $\begin{array}{l}\text { TK- } \\
2019 \mathrm{II} / 880 \\
45 / \mathrm{INV} \\
\end{array}$ & $\begin{array}{l}\text { Kapal Api Spesial Mix, Kapal } \\
\text { Api Susu 32gr }\end{array}$ \\
\hline 9 & & $\begin{array}{l}\text { TK- } \\
2019 \mathrm{II} / 881 \\
15 / \mathrm{INV}\end{array}$ & $\begin{array}{l}\text { Indocafe Coffemix 20gr, } \\
\text { Kapal Api } 165 \text { Gr, Kapal Api } \\
\text { Spesial Mix, Tongtji } \\
\text { Jasmine, Tongtji Jasmine } \\
\text { Tanpa Amplop }\end{array}$ \\
\hline
\end{tabular}
bantuan Software RapidMiner. Berikut adalah

\begin{tabular}{|c|c|c|c|}
\hline 10 & & \begin{tabular}{|l|} 
TK- \\
$2019 \mathrm{II} / 881$ \\
$27 / \mathrm{INV}$
\end{tabular} & $\begin{array}{l}\text { Beras Ramos Kembang 5kg, } \\
\text { Bimoli 2lt Ref }\end{array}$ \\
\hline 11 & $\begin{array}{c}6-\mathrm{Feb}- \\
19\end{array}$ & $\begin{array}{l}\text { TK- } \\
2019 \mathrm{II} / 8 \\
8130 / \mathrm{IN} \\
\mathrm{V}\end{array}$ & Beras Ramos Kembang 5kg \\
\hline 12 & $07-$ & \begin{tabular}{|l|} 
TK- \\
$2019 \mathrm{II} / 881$ \\
$43 / \mathrm{INV}$ \\
\end{tabular} & $\begin{array}{l}\text { Kapal Api } 165 \text { Gr, Tongtji } \\
\text { Jasmine Tanpa Amplop }\end{array}$ \\
\hline 13 & Feb-19 & \begin{tabular}{|l|} 
TK- \\
$2019 \mathrm{II} / 8$ \\
$8293 / \mathrm{IN}$ \\
$\mathrm{V}$
\end{tabular} & $\begin{array}{l}\text { Gulaku Kuning, Kapal Api } 165 \\
\text { Gr, Max Creamer 450gr, Teh } \\
\text { Sosro } 50\end{array}$ \\
\hline 14 & & $\begin{array}{l}\text { TK- } \\
2019 \mathrm{II} / 8 \\
8355 / \mathrm{IN} \\
\mathrm{V}\end{array}$ & $\begin{array}{l}\text { Gulaku Putih, Indocafe Jar } \\
\text { 200g, Kapal Api } 165 \text { Gr, } \\
\text { Teh Sosro } 50\end{array}$ \\
\hline 15 & & $\begin{array}{l}\text { TK- } \\
2019 \mathrm{II} / 8 \\
8385 / \mathrm{IN} \\
\mathrm{V}\end{array}$ & $\begin{array}{l}\text { Gulaku Kuning, Indocafe Jar } \\
\text { 200g, Kapal Api } 165 \mathrm{Gr}, \\
\text { Max Creamer } 450 \mathrm{gr} \text {, } \\
\text { Sariwangi } 50\end{array}$ \\
\hline 16 & & $\begin{array}{l}\text { TK- } \\
2019 \mathrm{II} / 8 \\
8390 / \mathrm{IN} \\
\mathrm{V}\end{array}$ & Gulaku Putih, Kapal Api 165 Gr \\
\hline 17 & Feb-19 & \begin{tabular}{|l} 
TK- \\
$2019 \mathrm{II} / 8$ \\
$8400 / \mathrm{IN}$ \\
$\mathrm{V}$
\end{tabular} & $\begin{array}{l}\text { Kapal Api } 165 \text { Gr, Tongtji } \\
\text { Premium 10gr }\end{array}$ \\
\hline 18 & & \begin{tabular}{|l|} 
TK- \\
$2019 \mathrm{II} / 8$ \\
$8408 / \mathrm{IN}$ \\
$\mathrm{V}$ \\
\end{tabular} & Kapal Api 165 Gr \\
\hline 19 & & $\begin{array}{l}\text { TK- } \\
2019 \mathrm{II} / 8 \\
8456 / \mathrm{IN} \\
\mathrm{V}\end{array}$ & $\begin{array}{l}\text { Gulaku Kuning, Kapal Api } \\
165 \mathrm{Gr} \text {, Max Creamer } \\
\text { 450gr, Sariwangi 50, } \\
\text { Tongtji Jasmine }\end{array}$ \\
\hline 20 & & $\begin{array}{l}\text { TK- } \\
2019 \mathrm{II} / 8 \\
8504 / \mathrm{IN} \\
\mathrm{V}\end{array}$ & $\begin{array}{l}\text { Gulaku Kuning, Indocafe Jar } \\
\text { 200g, Kapal Api } 165 \mathrm{Gr}, \\
\text { Max Creamer 450gr, Teh } \\
\text { Celup Sosro } 30\end{array}$ \\
\hline 21 & & $\begin{array}{l}\text { TK- } \\
2019 \mathrm{II} / 8 \\
8552 / \mathrm{IN} \\
\mathrm{V}\end{array}$ & $\begin{array}{l}\text { Kapal Api } 165 \text { Gr, Max } \\
\text { Creamer Ref 500gr, Tongtji } \\
\text { Jasmine Tanpa Amplop, } \\
\text { Tropicanaslim Classic 100gr }\end{array}$ \\
\hline ..... & $\ldots \ldots \ldots . . . .$. & 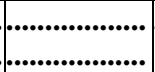 & 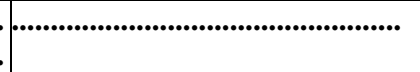 \\
\hline ...... & (................................ & 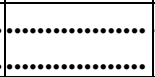 & 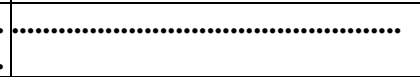 \\
\hline ...... & (n............................. & 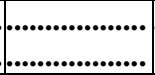 & 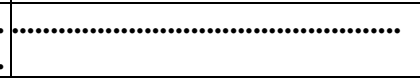 \\
\hline 99 & & \begin{tabular}{|l|} 
TK- \\
2019II/908 \\
O6/INV
\end{tabular} & $\begin{array}{l}\text { Bimoli 1lt Ref, Kapal Api } 165 \\
\text { Gr, Torabika Cappucino 25gr }\end{array}$ \\
\hline
\end{tabular}
transaksi penjualan selama sebulan.

Tabel 1. Data Transaksi Penjualan 


\begin{tabular}{|c|c|c|c|}
\hline 100 & $\begin{array}{c}27- \\
\text { Feb-19 }\end{array}$ & $\begin{array}{l}\text { TK- } \\
2019 \mathrm{II} / 908 \\
\text { 09/INV }\end{array}$ & $\begin{array}{l}\text { Kapal Api Spesial Mix, } \\
\text { Torabika Cappucino 25gr, }\end{array}$ \\
\hline 101 & & \begin{tabular}{|l|} 
TK- \\
$2019 \mathrm{II} / 908$ \\
$18 / \mathrm{INV}$
\end{tabular} & $\begin{array}{l}\text { Beras Ramos Kembang 20kg, } \\
\text { Kapal Api } 165 \mathrm{Gr}\end{array}$ \\
\hline 102 & $27-$ & $\begin{array}{l}\text { TK- } \\
\text { 2019II/908 } \\
59 / \text { INV }\end{array}$ & Kapal Api 165 Gr \\
\hline 103 & & $\begin{array}{l}\text { TK- } \\
\text { 2019II/908 } \\
89 / \mathrm{INV}\end{array}$ & Kapal Api Spesial Mix \\
\hline 104 & \multirow{5}{*}{$\begin{array}{c}28- \\
\text { Feb-19 }\end{array}$} & \begin{tabular}{|l|} 
TK- \\
$2019 \mathrm{II} / 909$ \\
$49 / \mathrm{INV}$
\end{tabular} & $\begin{array}{l}\text { Gulaku Kuning, Kapal Api } \\
165 \mathrm{Gr} \text {, Beras Ramos Hong } \\
10 \mathrm{~kg} \text {, Torabika Cappucino } \\
25 \mathrm{gr}\end{array}$ \\
\hline 105 & & \begin{tabular}{|l|} 
TK- \\
2019II/909 \\
77/INV \\
\end{tabular} & $\begin{array}{l}\text { Gulaku Kuning, Indocafe Jar } \\
\text { 200g, Kapal Api } 165 \text { Gr, Max } \\
\text { Creamer 450gr, Sariwangi 50, } \\
\text { Tongtji Jasmine, Tongtji } \\
\text { Jasmine Tanpa Amplop }\end{array}$ \\
\hline 106 & & $\begin{array}{l}\text { TK- } \\
2019 \mathrm{II} / 910 \\
01 / \mathrm{INV}\end{array}$ & $\begin{array}{l}\text { Gulaku Putih, Kapal Api } 165 \\
\text { Gr, Max Creamer 450gr }\end{array}$ \\
\hline 107 & & $\begin{array}{l}\text { TK- } \\
2019 \mathrm{II} / 910 \\
14 / \mathrm{INV}\end{array}$ & Beras Ramos Kembang 20kg \\
\hline 108 & & $\begin{array}{l}\text { TK- } \\
2019 \mathrm{II} / 910 \\
16 / \mathrm{INV}\end{array}$ & Kapal Api 165 Gr \\
\hline
\end{tabular}

Tabel 2. Format Tabular

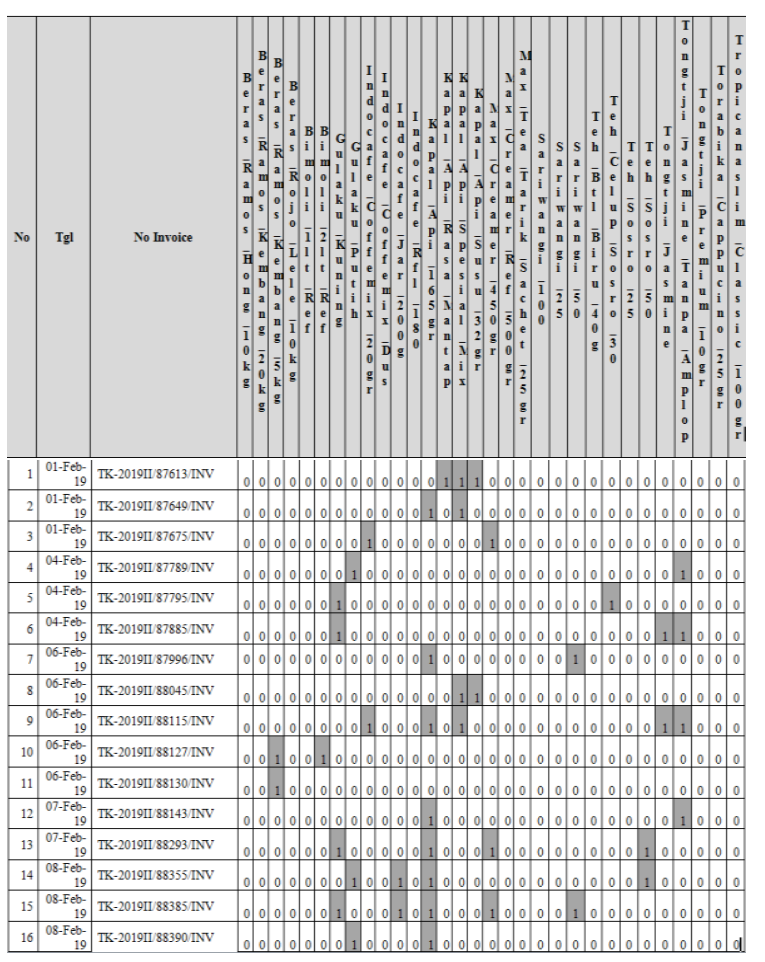

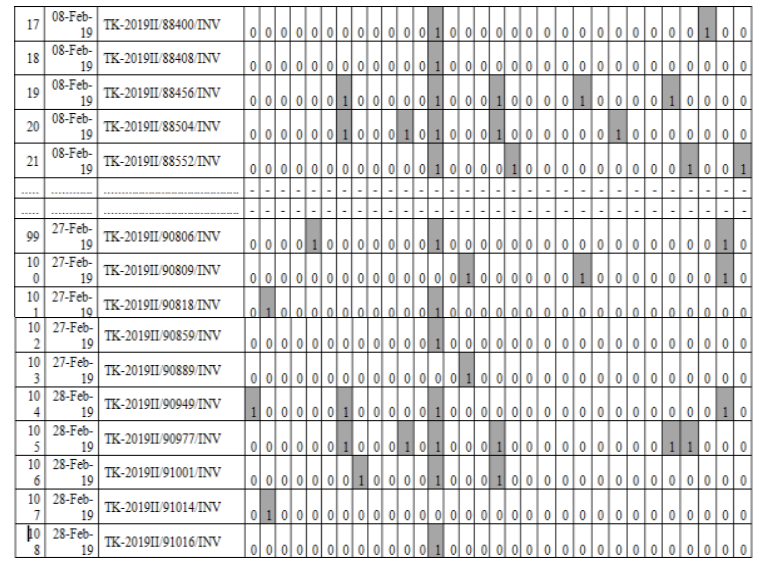

a. Pembentukan 1 itemset

Proses pembentukan $\mathrm{C}_{1}$ atau disebut dengan 1 itemset dengan jumlah minimum support $=\mathbf{2 0} \%$ Support $(\mathrm{A})=\frac{\sum \text { transaksi yang mengandung A }}{\sum \text { transaksi }} \times 100 \%$

Tabel 3. Support ItemSet 1

\begin{tabular}{|l|l|r|}
\hline \multicolumn{1}{|c|}{ Nama Barang } & $\begin{array}{c}\text { Support } \\
\text { Count }\end{array}$ & $\begin{array}{c}\text { Support } \\
(\%)\end{array}$ \\
\hline Beras Ramos Hong 10kg & $2 / 108$ & $1,85 \%$ \\
\hline Beras Ramos Kembang 20kg & $2 / 108$ & $1,85 \%$ \\
\hline Beras Ramos Kembang 5kg & $2 / 108$ & $1,85 \%$ \\
\hline Beras Rojo Lele 10kg & $2 / 108$ & $1,85 \%$ \\
\hline Bimoli 1lt Ref & $3 / 108$ & $2,78 \%$ \\
\hline Bimoli 2lt Ref & $5 / 108$ & $4,62 \%$ \\
\hline Gulaku Kuning & $\mathbf{4 5 / 1 0 8}$ & $\mathbf{4 1 , 6 7 \%}$ \\
\hline Gulaku Putih & $\mathbf{2 5 / 1 0 8}$ & $\mathbf{2 3 , 1 5 \%}$ \\
\hline Indocafe Coffemix 20gr & $4 / 108$ & $3,73 \%$ \\
\hline Indocafe Coffemix Dus & $3 / 108$ & $2,78 \%$ \\
\hline Indocafe Jar 200g & $\mathbf{2 3 / 1 0 8}$ & $\mathbf{2 1 , 3 0 \%}$ \\
\hline Indocafe Rfl 180 & $2 / 108$ & $1,85 \%$ \\
\hline Kapal Api 165 Gr & $\mathbf{6 5 / 1 0 8}$ & $\mathbf{6 0 , 1 9 \%}$ \\
\hline Kapal Api Rasa Mantap & $6 / 108$ & $5,56 \%$ \\
\hline Kapal Api Spesial Mix & $9 / 108$ & $8,33 \%$ \\
\hline Kapal Api Susu 32gr & $3 / 108$ & $2,78 \%$ \\
\hline Max Creamer 450gr & $\mathbf{2 4 / 1 0 8}$ & $\mathbf{2 2 , 2 2 \%}$ \\
\hline Max Creamer Ref 500gr & $8 / 108$ & $7,41 \%$ \\
\hline Max Tea Tarik Sachet 25gr & $4 / 108$ & $3,73 \%$ \\
\hline Sariwangi 100 & $2 / 108$ & $1,85 \%$ \\
\hline Sariwangi 25 & $4 / 108$ & $3,73 \%$ \\
\hline Sariwangi 50 & $\mathbf{2 7 / 1 0 8}$ & $\mathbf{2 5 \%}$ \\
\hline Teh Btl Biru 40g & $4 / 108$ & $3,73 \%$ \\
\hline Teh Celup Sosro 30 & $8 / 108$ & $7,41 \%$ \\
\hline Teh Sosro 25 & $3 / 108$ & $2,78 \%$ \\
\hline Teh Sosro 50 & $8 / 108$ & $7,41 \%$ \\
\hline Tongtji Jasmine & $10 / 108$ & $9,25 \%$ \\
\hline
\end{tabular}




\begin{tabular}{|l|l|r|}
\hline Tongtji Jasmine Tanpa Amplop & $16 / 108$ & $14,81 \%$ \\
\hline Tongtji Premium 10gr & $3 / 108$ & $2,78 \%$ \\
\hline Torabika Cappucino 25gr & $9 / 108$ & $8,33 \%$ \\
\hline Tropicanaslim Classic 100gr & $3 / 108$ & $2,78 \%$ \\
\hline
\end{tabular}

b. Pembentukan kombinasi 2 ItemSet

Proses pembentukan $\mathrm{C}_{2}$ atau disebut dengan 2 itemset dengan jumlah minimum support $=$ $>\mathbf{2 0 \%}$

$$
\begin{aligned}
& \text { Support }(A, B)=P(A \cap B) \\
& \text { Supprot }(A, B) \\
& \text { Support }(A, B)=\frac{\sum \text { Transaksi yang mengandung A dan B }}{\sum \text { Tansaksi }} \times 100 \%
\end{aligned}
$$

\begin{tabular}{|c|c|c|}
\hline Nama Barang & $\begin{array}{l}\text { Support } \\
\text { Count }\end{array}$ & $\begin{array}{c}\text { Support } \\
(\%)\end{array}$ \\
\hline Gulaku Kuning, Gulaku Putih & $0 / 108$ & $0 \%$ \\
\hline $\begin{array}{l}\text { Gulaku Kuning, Indocafe Jar } \\
200 \mathrm{~g}\end{array}$ & $13 / 108$ & $12,04 \%$ \\
\hline $\begin{array}{l}\text { Gulaku Kuning, Kapal Api } \\
165 \mathrm{gr}\end{array}$ & 28/108 & $25,92 \%$ \\
\hline $\begin{array}{l}\text { Gulaku Kuning, Max Creamer } \\
450 \mathrm{gr}\end{array}$ & $14 / 108$ & $12,97 \%$ \\
\hline Gulaku Kuning, Sariwangi 50 & $13 / 108$ & $12,04 \%$ \\
\hline Gulaku Putih, Indocafe Jar 200g & $10 / 108$ & $9,26 \%$ \\
\hline Gulaku Putih, Kapal Api 165gr & $19 / 108$ & $17,60 \%$ \\
\hline $\begin{array}{l}\text { Gulaku Putih, Max Creamer } \\
\text { 450gr }\end{array}$ & $9 / 108$ & $8,33 \%$ \\
\hline Gulaku Putih, Sariwangi 50 & $10 / 108$ & $9,26 \%$ \\
\hline $\begin{array}{l}\text { Indocafe Jar 200g, Kapal Api } \\
165 \mathrm{gr}\end{array}$ & $23 / 108$ & $21,30 \%$ \\
\hline $\begin{array}{lrrr}\text { Indocafe Jar } 200 g, & \text { Max } \\
\text { Creamer 450gr } & & \\
\end{array}$ & $18 / 108$ & $16,67 \%$ \\
\hline Indocafe Jar 200g, Sariwangi 50 & $14 / 108$ & $12,70 \%$ \\
\hline $\begin{array}{l}\text { Kapal Api 165gr, Max Creamer } \\
450 \text { gr }\end{array}$ & $23 / 108$ & $21,30 \%$ \\
\hline Kapal Api 165gr, Sariwangi 50 & $21 / 108$ & $19,44 \%$ \\
\hline $\begin{array}{l}\text { Max Creamer 450gr, Sariwangi } \\
50\end{array}$ & $13 / 108$ & $12,04 \%$ \\
\hline
\end{tabular}

Tabel 4. Support Kombinasi 2 ItemSet

c. Pembentukan kombinasi 3 itemSet

Proses pembentukan $\mathrm{C}_{3}$ atau disebut dengan 3 itemset dengan jumlah minimum support $=$ $>\mathbf{2 0 \%}$

Support $(A, B)=P(A \cap B \cap C)$

Supprot $(\mathrm{A}, \mathrm{B}$ dan $\mathrm{C})$

Support $(A, B$ dan $C)=\frac{\sum \text { Transaksi yang mengandung } A, B \text { dan } C}{\sum \text { Tansaksi }} \times 100 \%$

Tabel 5. Support Kombinasi 3 ItemSet

\begin{tabular}{|l|c|r|}
\hline \multicolumn{1}{|c|}{ Nama Barang (Itemset) } & Jml & Support (\%) \\
\hline $\begin{array}{l}\text { Gulaku Kuning, Kapal Api } \\
\text { 165g, Indocafe Jar 200g }\end{array}$ & $13 / 108$ & $12,03 \%$ \\
\hline $\begin{array}{l}\text { Gulaku Kuning, Indocafe Jar } \\
\text { 200, Max Creamer 450gr }\end{array}$ & $12 / 108$ & $11,11 \%$ \\
\hline Gulaku Kuning, Kapal Api & $14 / 108$ & $12,97 \%$ \\
\hline
\end{tabular}

\begin{tabular}{|l|l|l|}
\hline 165g, Max Creamer 450gr & & \\
\hline Kapal Api 165g, Indocafe & $18 / 108$ & $16,67 \%$ \\
Jar 200, Max Creamer 450gr & & \\
\hline
\end{tabular}

Karena kombinasi 3 itemset tidak ada yang memenuhi minimal support, maka kombinasi 2 itemset yang memenuhi untuk pembentukan aturan asosiasi.

d. Pembentukan aturan asosiasi

Pembentukan Aturan Asosiatif, setelah semua pola frekuensi tinggi ditemukan, barulah dicari aturan asosiatif yang memenuhi syarat minimum untuk confidence dengan menghitung confidence aturan asosiatif $\mathrm{A} \rightarrow \mathrm{B}$. Dengan min confidence $=$ $>60 \%$

$$
\text { Confidence }=P(A \mid B)=\frac{\sum \text { Transaksi yang mengandung A dan } B}{\sum \text { Tansaksi } A} \times 100 \%
$$

Tabel 6. Aturan asosiasi

\begin{tabular}{|l|c|c|}
\hline \multicolumn{1}{|c|}{ Aturan } & \multicolumn{2}{c|}{ Confidence } \\
\hline $\begin{array}{l}\text { Jika membeli Gulaku Kuning, } \\
\text { maka akan membeli Kapal Api } \\
165 \mathrm{gr}\end{array}$ & & \\
\hline $\begin{array}{l}\text { Jika membeli Kapal Api 165gr, } \\
\text { maka akan membeli Gulaku }\end{array}$ & & \\
Kuning & $28 / 65$ & $43,18 \%$ \\
\hline $\begin{array}{l}\text { Jika membeli Indocafe Jar 200g, } \\
\text { maka akan membeli Kapal Api } \\
165 g r\end{array}$ & & \\
\hline $\begin{array}{l}\text { Jika membeli Kapal Api 165gr, } \\
\text { maka akan membeli Indocafe Jar } \\
\text { 200g }\end{array}$ & $23 / 23$ & $100 \%$ \\
\hline $\begin{array}{l}\text { Jika membeli kapal api 165gr, } \\
\text { maka akan membeli Max Creamer }\end{array}$ & & \\
450gr & $23 / 65$ & $35,38 \%$ \\
\hline $\begin{array}{l}\text { Jika membeli Max Creamer } \\
\text { 450gr, maka akan membeli Kapal } \\
\text { Api 165gr }\end{array}$ & $23 / 24$ & $95,83 \%$ \\
\hline
\end{tabular}

\begin{tabular}{|c|c|c|}
\hline Aturan Final & Support & Confidence \\
\hline $\begin{array}{l}\text { Jika Membeli INDOCAFE } \\
\text { JAR 200G, maka akan } \\
\text { membeli KAPAL API 165GR }\end{array}$ & $21,30 \%$ & $100 \%$ \\
\hline $\begin{array}{l}\text { Jika Membeli } \\
\text { CREAMER 450GR, maka } \\
\text { akan membeli KAPAL API } \\
\text { 165GR }\end{array}$ & $21,30 \%$ & $95,83 \%$ \\
\hline $\begin{array}{l}\text { Jika Membeli GULAKU } \\
\text { KUNING, maka akan } \\
\text { membeli KAPAL API 165GR }\end{array}$ & $25,92 \%$ & $62,22 \%$ \\
\hline
\end{tabular}

maka yang memenuhi minimal Support $>20 \%$ dan Confidence $>60 \%$ adalah sebagai berikut:

Tabel 7. Aturan Asosiasi Final

Dengan hasil aturan asosiasi diatas, produk kebutuhan pokok di Swalayan Koperasi Pegawai Bappenas yang paling banyak terjual adalah Gulaku Kuning, Indocafe Jar 200g, Kapal Api 165gr, dan Max Creamer 450gr dengan diketahui produk kebutuhuan pokok yang banyak terjual 
koperasi dapat menambahkan persediaan stok barang tersebut.

e. Perhitungan dengan Software Rapid Miner Dibawah ini merupakan langkah-langkah kerja pada Rapid Miner, yaitu sebagai berikut:

1) Pembuatan From Tabular pada lembar kerja Ms. Exel seperti pada tabel 2.

2) Buka aplikasi Software Rapid Miner dan pilih File-New atau bisa langsung klik New.

3) Kemudian akan tampil tampilan design perspective atau bisa dibilang dengan lingkungan kerja Rapid Miner.

4) Selanjutnya untuk mengimport data .xls, pada no. 1 terdapat Operator View yang dimana berisi langkah kerja rapid miner, setelah itu pilih import yang digunakan untuk membaca data dan objek dari format tertentu, lalu untuk membaca data .xls pilih Data dan klik 2 kali atau drag drop Read Excel pada main proses terlihat pada no. 2.

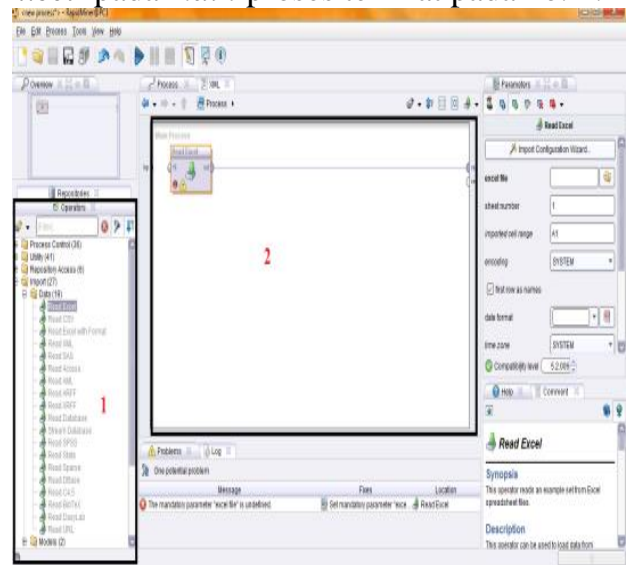

Gambar 1. Tampilan Kelompok Operator View dan Read Exel dalam Main Process

5) Setelah itu untuk mengimport data .xls pada Parameters View terdapat Import Congfiguration Wizard yang berfungsi untuk mengimport data .xls dari komputer.

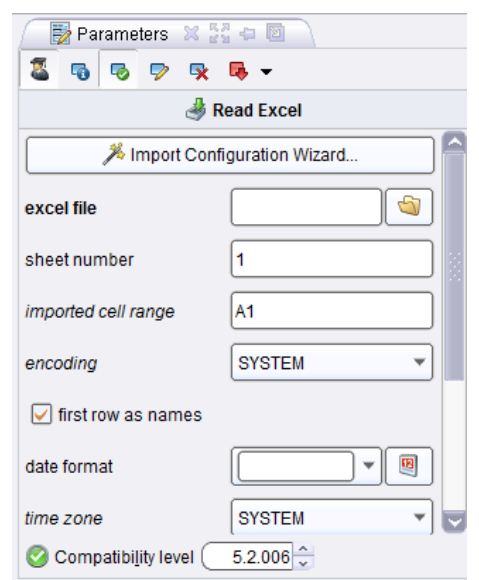

Gambar IV.2 Tampilan Parameter Read Excel
6) Setelah melakukan import data transaksi_penjualan.xls, selanjutnya memasukan operator, yaitu Numerical to

7) Binomial, FP Growth, Create Association Rule

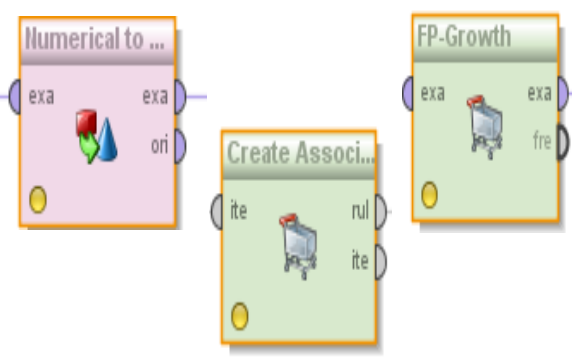

Gambar 3. Operator View Numerical to Binominal, Fp Growth, Create Association Rule

8) Isi parametrs FP-Growth dengan minimal support yang sudah ditentukan, yaitu $20 \%$ atau 0.2. dan Isi Parameters Create Association Rule dengan min confidence yang sudah di tentukan, yaitu, $60 \%$ atau 0.6

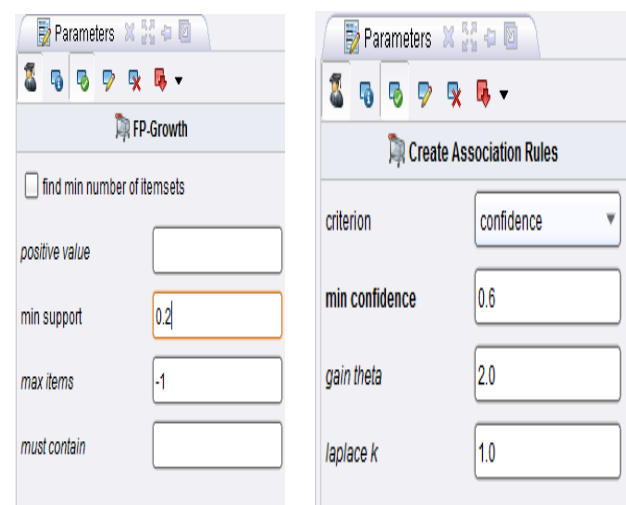

Gambar 4. Menentukan min support dan min confidence

9) Hubungkan semua operator, seperti gambar dibawah ini, lalu klik ikon play

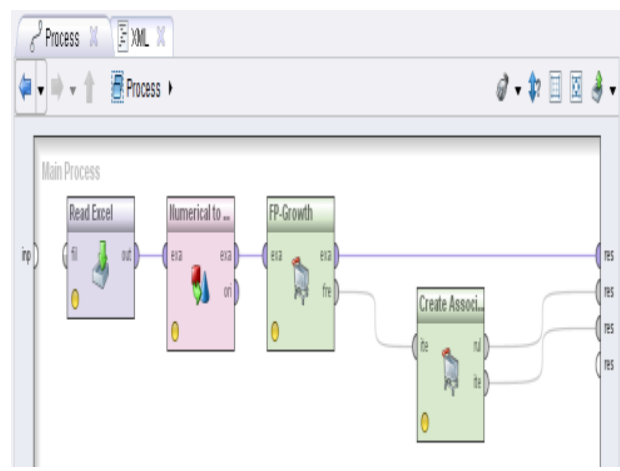

Gambar 5. Susunan Operator Association Rule 
10) Setelah itu muncul hasil dari perhitungan itemset $\mathrm{C}_{1}$ dan $\mathrm{C}_{2}$ yang memenuhi syarat min support $20 \%$ atau 0.2 .

\begin{tabular}{|c|c|c|}
\hline Support & Item 1 & Item 2 \\
\hline 0.602 & KAPAL_API_165GR & \\
\hline 0.417 & GULAKU_KUNING & \\
\hline 0.250 & SARIWANGI_50 & \\
\hline 0.231 & GULAKU_PUTIH & \\
\hline 0.222 & MAX_CREAMER_450GR & \\
\hline 0.213 & INDOCAFE_JAR_200G & \\
\hline 0.259 & KAPAL_API_165GR & GULAKU_KUNING \\
\hline 0.213 & KAPAL_API_165GR & MAX_CREAMER_450GR \\
\hline 0.213 & KAPAL_API_165GR & INDOCAFE_JAR_200G \\
\hline
\end{tabular}

11) Dan terlihat juga hasil final dari Association Rule yaitu berjumlah 3 Rules, dengan syarat min confidence $60 \%$ atau 0.6 .

\section{AssociationRules}

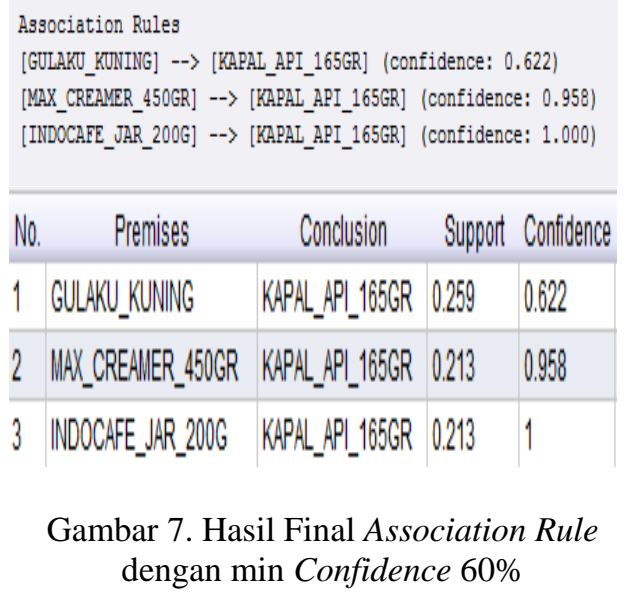

Gambar 7. Hasil Final Association Rule dengan min Confidence $60 \%$

12) Bentuk grafik dari hasil final Association Rule.

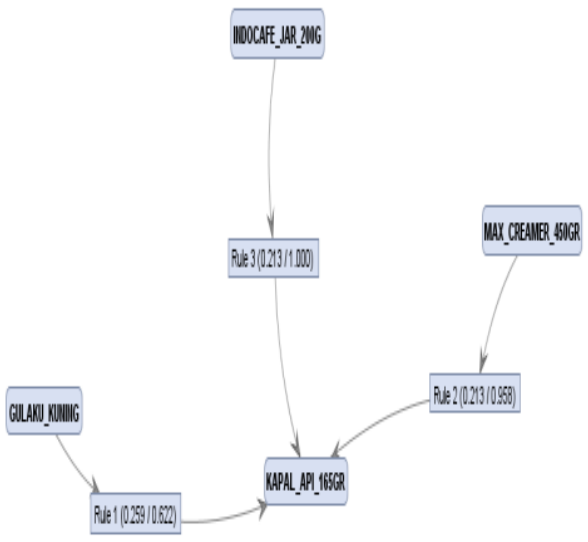

Gambar 8. Tampilan grafik hasil final Association Rule.

\section{KESIMPULAN}

1. Dengan perhitungan algoritma apriori sangat berguna untuk mengetahui hubungan pola frekuensi penjualan kebutuhan pokok yang paling sering dibeli secara bersamaan.

2. Hasil dari pengolahan data 108 transaksi melalui Software Rapid Miner terdapat 3 rules yang memenuhi syarat, yaitu Jika Membeli Indocafe Jar $200 \mathrm{~g}$, maka akan membeli Kapal Api 165 gr dengan nilai confidence $100 \%$, jika Membeli Max Creamer 450gr, maka akan membeli Kapal Api 165gr dengan nilai confidence $95,83 \%$, dan jika membeli Gulaku Kuning, maka akan membeli Kopi Kapal Api $165 \mathrm{gr}$ denga nilai confidence $62,22 \%$

3. Pola yang didapat bisa digunakan untuk membantu koperasi dalam menentukan keputusan membuat strategi pemasaran produk, sehingga data penjualan tidak hanya di jadikan arsip saja.

\section{REFERENSI}

Nofriansyah, D. (2014). Konsep Data Mining Vs Sistem Pendukung Keputusan. Yogyakarta: Deepublish.

Siregar, S. R. (2014). Implementasi Data Mining Pada Penjualan Tiket Pesawat Menggunakan Algoritma Apriori ( Studi Kasus: Jumbo Travel Medan ), 152, 152-156.

Syahdan, S. Al, \& Anita, S. (2018). Data Mining Penjualan Produk Dengan Metode Apriori Pada Indomaret Galang Kota. Nasional Komputasi Dan Teknologi Informasi, 1, 5663.

Wijaya, K. N. (2017). Analisa Pola Frekuensi Keranjang Belanja Dengan Algoritma Apriori, 3(1), 9-12. 


\section{PROFIL PENULIS}

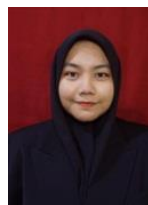

Penulis pertama bernama Siti Aisyah merupakan mahasiswa tingkat akhir STMIK Nusa mandiri dan juga Alumni dari Universitas Bina Sarana Informatika.

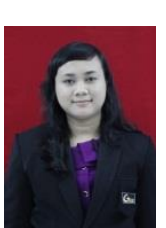

Penulis kedua Normah, memperoleh gelar Master Komputer (M.Kom), Jurusan Magister Ilmu Komputer Program Pasca Sarjana STMIK Nusa
Mandiri Jakarta, lulus tahun 2014. Saat ini menjadi Dosen di STMIK Nusa Mandiri (S1) Jakarta. 